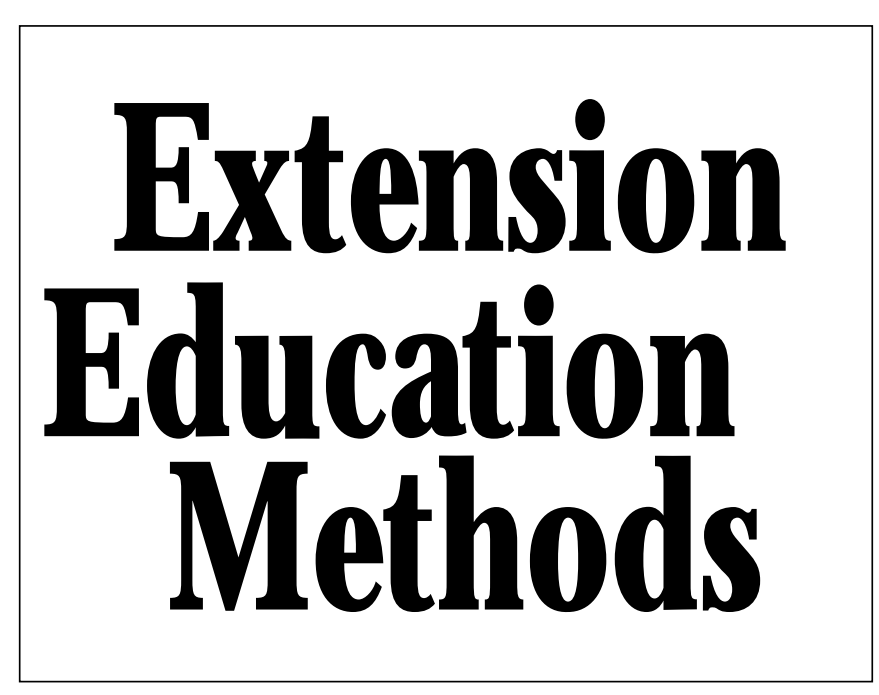

\section{Reasons for Becoming Involved as a Master Gardener}

\author{
D enny S. Schrock, ${ }^{1} \mathrm{M}$ ary M eyer, ${ }^{2}$ \\ Peter Ascher, ${ }^{3}$ and $M$ ark Snyder ${ }^{4}$
}

AdDitIONAL INDEX WORDS. volunteer, extension, motivation, volunteer retention, volunteer demographics

\begin{abstract}
Summary. C urrent and former $M$ issouri $M$ aster $\mathbf{G}$ ardeners were asked to respond to each of 30 reasons (an adaptation of the Volunteer F unctions I nventory [VFI]) for doing volunteer work. Principal factor analysis confirmed the presence of six principal components of volunteer motivation. $M$ aster $\mathbf{G}$ ardener functions related to new learning experiences (understanding) were equally as important as functions related to altruism (values). Satisfactions related to self-esteem (enhancement) ranked next in motivational importance. M otivations concerning relationships with others (social), protecting the ego (protective) and functions related to preparation for a new career (career), concluded the list. In addition, respondents were asked to indicate whether they were presently volunteering as a $M$ aster $\mathbf{G}$ ardener, how many years they had been active in the program, and level of volunteer time commitment to the program in the past year. In most cases, no correlations or statistical differences were found among respondents belonging to different demographic categories, making demographic information a poor predictor of motivation for volunteering. H owever, those who volunteered more time during the past year were more likely to highly rate certain motivational factors.
\end{abstract}

\footnotetext{
The cost of publishing this paper was defrayed in part by the payment of page charges. U nder postal regulations, this paper therefore must be hereby marked advertisement solely to indicate this fact.

${ }^{1}$ Extension specialist, U niversity of I llinois, U rbana, IL 61801.

${ }^{2}$ Assistant professor, U niversity of M innesota, St. Paul, M N 55108.

${ }^{3}$ Professor, U niversity of M innesota, St. Paul, M N 55108.

${ }^{4}$ Professor, U niversity of M innesota, M inneapolis, M N 55455.
}

$\mathrm{T}$

he M aster Gardener program originated at Washington State U niv. in 1972 in response to an overwhelming demand for consumer horticulture information and limited extension service resources to meet those demands. The mission of the M aster Gardener program is to promote gardening, to inform the public about current horticultural practices, to enhance environmental conservation, and to broaden communities' gardening expertise (Guest, 1997). To achieve these goals, thousands of new volunteers are trained annually to teach others by extension specialists and educators. The objectives of this study were to determine the demographics of $M$ issouri $M$ aster $G$ ardener volunteers, and why they chose to become involved as an extension volunteer.

Understanding why people volunteer has been the subject of much research (Ellis, 1993; Gordon and Babchuk, 1959; Henderson, 1981; Piliavin and Charng, 1990; Sundeen, 1992; Thompson and Bono, 1993). In its simplest form, motivation for volunteering may be viewed as one of two incentives: helping others (altruism) or helping oneself (Piliavin and C harng, 1990; Stebbins 1996). Piliavin and Charng (1990) report that early studies of volunteer behavior took the position that under close scrutiny, all behavior must reflect egoistic motives. $\mathrm{H}$ owever, current theory and data view that true altruism does exist and is a part of human nature. Thecoprovision/ coproduction theory of volunteerism involves aspects of both altruism and selfinterest (Ferris, 1984; Sundeen, 1988). Coprovision was defined by Ferris (1984) as the "voluntary involvement of citizens in provision of publicly provided goods and services or close substitutes." Sundeen (1988) used the term coproduction to refer to activities in which citizens' volunteer time results in an increased level of public goods and services for a community either through citizens working directly under the auspices of a governmental agency or through volunteer investment of time in not-for-profit organizations. Thisdefinition of coproduction fitsthemodel of the extension M aster $\mathrm{G}$ ardener program where participants take horticultural training provided by the state's land-grant university system, and in turn volunteer to provide horticultural educational services to the local community.

Volunteerism may be viewed either as leisure (H enderson, 1981, 1984; Stebbins, 1996) or as career related (Ellis, 1993; Jenner, 1981). H enderson (1981) found that adult volunteers in the $4-\mathrm{H}$ youth program described their volunteering as being a leisure activity. They were most motivated to volunteer for affiliation or social purposes, as evidenced by their need to interact with others. J enner (1981) found in a mail survey that women view their volunteer role as either 1) consciously chosen primary work, 2) a supplement to primary work, or 3) a vehicle for entry or return to employment. Ellis (1993) concurs that volunteering can foster career development as well as enhance the job search process.

\section{Materials and methods}

As part of a more extensive mail survey on $M$ aster Gardener motivation and retention (Schrock et al., 1999, 2000), 417 randomly selected current and former $M$ issouri $M$ aster $G$ ardeners were asked to respond to their reasonsfor volunteering. Respondents were asked to indicate how important each of 30 reasons was for them in doing volun- 
Table 1. Demographic parameters of $M$ issouri M aster $G$ ardeners responding to the Volunteer $F$ unctions Inventory (VFI) survey.

\begin{tabular}{|c|c|}
\hline Parameter & $\begin{array}{c}\text { R espondents } \\
(\%)\end{array}$ \\
\hline \multicolumn{2}{|l|}{ Age (years) } \\
\hline$<40$ & 13.7 \\
\hline $40 \mathrm{~s}$ & 27.1 \\
\hline $50 \mathrm{~s}$ & 23.5 \\
\hline $60 \mathrm{~s}$ & 24.5 \\
\hline$\geq 70$ & 11.2 \\
\hline \multicolumn{2}{|l|}{ Gender } \\
\hline Female & 65.0 \\
\hline M ale & 35.0 \\
\hline \multicolumn{2}{|l|}{ Relationship status } \\
\hline M arried & 82.5 \\
\hline D ivorced/ widowed/ separated & 13.1 \\
\hline Single & 4.4 \\
\hline \multicolumn{2}{|l|}{$\mathrm{H}$ ave children } \\
\hline Yes & 86.2 \\
\hline No & 13.8 \\
\hline \multicolumn{2}{|l|}{ O ccupation } \\
\hline Retired & 26.9 \\
\hline Professional/ medical/ education & 22.5 \\
\hline Trade/ technical & 18.2 \\
\hline H omemaker & 14.6 \\
\hline Business/ sales/ service & 12.2 \\
\hline Other & 5.6 \\
\hline \multicolumn{2}{|l|}{$\mathrm{H}$ ighest level of education } \\
\hline $\mathrm{H}$ igh school graduate & 11.6 \\
\hline Some college & 35.3 \\
\hline College graduate & 30.9 \\
\hline Postgraduate & 22.2 \\
\hline \multicolumn{2}{|l|}{ Income Level } \\
\hline Under $\$ 20,000$ & 10.3 \\
\hline$\$ 20,000-\$ 39,999$ & 33.2 \\
\hline$\$ 40,000-\$ 59,999$ & 23.3 \\
\hline$\$ 60,000$ or more & 33.2 \\
\hline \multicolumn{2}{|l|}{ Residence } \\
\hline City $>250,000$ & 21.7 \\
\hline City $25,000-249,999$ & 24.3 \\
\hline Area $<25,000$ & 53.9 \\
\hline \multicolumn{2}{|l|}{ Years at present location } \\
\hline$<5$ & 18.5 \\
\hline $5-10$ & 24.3 \\
\hline$>10$ & 57.2 \\
\hline
\end{tabular}

teer work through the university outreach and extension $M$ aster $G$ ardener program. If they were no longer active, they were asked to answer the questions to the best of their recollection of when they were involved as a M aster Gardener. Responses were based on a seven-point Likert-like scale ( $M$ atell and Jacoby, 1972) from 1 (not at all important/ accurate) to 7 (extremely important/ accurate). The initial mailing resulted in 216 responses. A followup mailing to nonrespondents brought in another 66 responses for a total of 282 responses, a $67.6 \%$ response rate. Respondents to the first mailing were more likely to be currently active volunteers than respondents to the second mailing ( $72 \% \mathrm{vs}$. $52 \%, \mathrm{P}<0.01$ ). H owever, other demographic categories and responses to questions, with one exception noted below, did not differ significantly between the two groups. Thus no adjustments in data analysis were made for nonrespondents.

The survey instrument was an adaptation of the Volunteer Functions I nventory developed by Clary et al. (1998). The adaptation includes five questions for each of six principal components of volunteer motivation: $U$ nderstanding (U), Values (V), Enhancement (E), Social (S), Protective $(P)$, and $C$ areer $(C)$. Principal factor analysis confirmed the presence of six principal components. The reliability of the six principal components was measured by Cronbach's al pha coefficient for internal consistency (C ronbach, 1951), which was 0.93 for all factors.

D emographic questions included age, gender, marital relationship status, ages of children, household income, occupation, level of education, location and length of residence. In addition, respondents were asked to indicate whether they were presently volunteering as a M aster $\mathrm{G}$ ardener, how many years they had been active as $M$ aster Gardener volunteers, and level of volunteer time commitment to the $\mathrm{M}$ aster $\mathrm{G}$ ardener program in the past year.

\section{Results and discussion}

$M$ ost respondents were married women with children and at least some college education (T able 1 ). A bout half were in their 40 s or $50 \mathrm{~s}$, and had lived in communities with a population of less than 25,000 for more than 10 years. Retired individuals and professionals constituted the largest occupational categories.

0 ver two-thirds of respondents were presently active (defined as $20 \mathrm{~h}$ or more of volunteer service per year) as $\mathrm{M}$ aster $\mathrm{G}$ ardener volunteers (Table 2). A plurality of respondents was currently volunteering 20 to $40 \mathrm{~h} /$ year and had been active in the program for 2 to 5 years. M ost $M$ aster Gardener programs in M issouri require $30 \mathrm{~h}$ of volunteer service the first year and $20 \mathrm{~h}$ in succeeding years for participants to remain active $\mathrm{M}$ aster $\mathrm{G}$ ardeners. The $\mathrm{M}$ aster Gardener program began in thestatein 1983, but most local $M$ aster $\mathrm{G}$ ardener organizations in the state were new within the 5 years before the survey.

O verall means for the six principal components of volunteer motivation are reported in Table 3. M aster $\mathrm{G}$ ar-

T able 2. Volunteer activity of M issouri Master $\mathbf{G}$ ardeners responding to the Volunteer F unctions I nventory (VFI) survey.

\begin{tabular}{lr} 
Activity & $\begin{array}{r}\text { R esponden } \\
\text { (\%) }\end{array}$ \\
\hline $\begin{array}{l}\text { Presently volunteering as M aster G ardener } \\
\text { Yes }\end{array}$ & \\
N o & 68.0 \\
H ours volunteered in last year & 32.0 \\
N one & \\
$1-20$ & 22.4 \\
$20-40$ & 20.9 \\
$\geq 40$ & 31.4 \\
N umber of years active & 25.3 \\
$0-1$ & \\
$2-5$ & 40.6 \\
$6-10$ & 45.7 \\
$\geq 10$ & 8.3 \\
\end{tabular}


T able 3. Principal motivation factors of M issouri Master $G$ ardeners responding to the Volunteer $F$ unctions I nventory (VFI) survey.

\begin{tabular}{ll}
\hline Principal factor & Mean $^{\mathbf{z}}$ \\
\hline U nderstanding (U) & $5.25 \mathrm{a}$ \\
Values (V) & $5.19 \mathrm{a}$ \\
Enhancement (E) & $3.98 \mathrm{~b}$ \\
Social (S) & $3.42 \mathrm{C}$ \\
Protective (P) & $2.73 \mathrm{~d}$ \\
Career (C) & $2.39 \mathrm{e}$
\end{tabular}

${ }^{2} \mathrm{M}$ eansfrom seven-point Likert scale: 1 =not at all important/ accurate, 7 =extremely important/ accurate. M eans followed by the same letter are not significantly different $(P=0.05)$ as determined by D uncan's multiple range test.

dener functions related to new learning experiences, (exercising knowledge, skills, and abilities) categorized as $U$, were equally as important as functions related to altruism and humanitarian concern, labeled as $\mathrm{V}$. O verall means for $\mathrm{U}$ and $\mathrm{V}$ were greater than 5 on the seven-point Likert scale, and they did not differ significantly from one another according to Duncan's multiple range test. Each of the other volunteer motivation categories differed significantly from U nderstanding and Values and from each other.
Satisfactions related to personal growth and self-esteem, labeled $\mathrm{E}$, ranked next in motivational importance. M otivations concerning relationships with others, classified as $\mathrm{S}$, led the second half of the list. Protecting the ego from negative features of self, reducing guilt over being more fortunate than others, and addressing one's own personal problems, labeled $\mathrm{P}$, was next in priority. And functions related to preparation for a new career or maintaining career-relevant skills, categorized as C, concluded the list.

In examining specific motivations for volunteering as an extension $M$ aster $\mathrm{G}$ ardener, 9 of the top 10 reasons were related to $\mathrm{U}$ or $\mathrm{V}$ (Table 4). The top two reasons were to learn more about horticulture and home gardening and learn horticulture through direct, hands-on experience. These results concur with the findings of Simonson and $P$ als (1990) who found the primary reason Idaho M aster Gardeners enrolled in the program was to increase knowledge for themselves. Finch (1997) also found that Texas volunteers applied to the $M$ aster $G$ ardener program primarily for the horticultural information; and Carlton (1981) determined a preference for more hands-on training activities among Florida M aster Gardeners. Responses to "allows me to gain a new perspective on things" and "can explore my own strengths", additional questions related to $U$, indicated

T able 4. R anking of motivational factors within the Volunteer F unctions I nventory (VFI) for M issouri M aster Gardeners volunteers.

Motivational

factor

1. L earn more about horticulture/ gardening

2. Learn horticulture through hands on experience

3. Feel it is important to help others

4. Genuinely concerned about home gardeners

5. Can do something for a horticultural cause

6. Feel compassion for people in need

7. Concerned about those less fortunate than myself

8. Allows me to gain new perspective on things

9. Way to make new friends

10. Can explore my own strengths

11. People I know share interest in community service

12. Can learn how to deal with a variety of people

13. Those close to me value community service highly

14. Increases my self-esteem

15. $\mathrm{H}$ elps me forget about how bad I've been feeling

16. H elps me feel better about myself

17. Volunteering important to those I know best

18. $M$ akes me feel needed

19. M akes me feel important

20. By volunteering I feel less lonely

21. Can make new contacts that help my career

22. Is a good escape from my own troubles

23. Will look good on my resume

24. H elps me work through my own problems

25. People I'm close to want me to volunteer

26. Will help me succeed in my chosen profession

27. Friends volunteer as $M$ aster $G$ ardeners

28. Allows me to explore different career options

29. Can help me get foot in door where I want to work

30. Relieves guilt over being more fortunate than others
VFI

category

Mean ${ }^{y}$

U

V

V

V

V

V

U

E

U

$\mathrm{S}$

U

$S$

E

P

E

$S$

E

P

C

$P$

C

P

$S$

C

$\mathrm{S}$

C

C

P
$6.37 \mathrm{a}$

$6.04 \mathrm{~b}$

$5.67 \mathrm{C}$

$5.29 d$

$5.08 \mathrm{e}$

$4.92 \mathrm{f}$

$4.88 \mathrm{f}$

$4.86 \mathrm{f}$

$4.74 \mathrm{~g}$

$4.61 \mathrm{~h}$

$4.41 \mathrm{i}$

$4.30 \mathrm{j}$

$4.16 \mathrm{k}$

$4.09 \mathrm{k}$

3.911

$3.88 \mathrm{~lm}$

$3.77 \mathrm{mn}$

$3.72 \mathrm{n}$

3.410

$2.77 \mathrm{p}$

$2.61 \mathrm{q}$

$2.46 \mathrm{r}$

$2.43 r$

$2.42 r$

$2.38 \mathrm{rs}$

2.37 rs

2.34 rs

$2.27 \mathrm{~s}$

$2.21 \mathrm{~s}$

$2.04 \mathrm{t}$

${ }^{2} \mathrm{M}$ eans from seven-point Likert scale: 1 = not at all important/ accurate, 7 = extremely important/ accurate. M eans followed by the same letter are not significantly different $(P=0.05)$ as determined by D uncan's multiple range test.

${ }^{y} \mathrm{C}$ ategories of motivation: $\mathrm{U}=$ understanding, $\mathrm{V}=$ values, $\mathrm{E}=$ enhancement, $\mathrm{P}=$ protective, $\mathrm{C}=$ career, and $\mathrm{S}=$ social. 
Table 5. C orrelation of M aster $\mathbf{G}$ ardener age with career-related volunteer motivational factors.

N ew contacts I make will help me in my career

Volunteering as $\mathrm{M}$ aster $\mathrm{G}$ ardener will look good on my resume

Allows me to explore different career options

$C$ an help me get my foot in the door at a place I'd like to work

$-0.28$

Will help me succeed in my chosen profession

zP $<0.01$ for all factors.

that advancing personal understanding was less important to $M$ aster $G$ ardeners than gaining technical horticultural knowledge.

M otivational factorsrelated to altruism and concern for others consistently ranked high, holding down places 3 through 7. This closely follows the pattern determined by Finch (1997) in which opportunity for community service ranked second to horticultural information as a reason for applying to the $\mathrm{M}$ aster $\mathrm{G}$ ardener program. $\mathrm{H}$ owever, results from the current study differ from those of Simonson and Pals (1990), where "to help others" ranked last out of six reasonsfor becoming an I daho $\mathrm{M}$ aster $\mathrm{G}$ ardener. A possible explanation for the discrepancy is the fact that respondents in thel daho survey wereforced to select a primary reason for becoming a $M$ aster $G$ ardener, and the other studies asked respondents to rate the importance of each reason rather than select a single reason.

The 10 least important reasons for volunteering as a $M$ aster Gardener in M issouri focused on $C, S$, and $P$ functions(Table4). Therewasno statistical differencein the low priority C reasons, "can help meget afoot in door where I want to work", and "allows me to explore different career options". Exploring career options did not differ from "friends volunteer as M aster Gardeners", "will help me succeed in my chosen profession", and "people I'm close to want me to volunteer". These latter three reasons also did not differ significantly from "helps me work through my own problems", "will look good on my resume", and "is a good escape from my own troubles". Slightly more important as a reason for volunteering was "I can make new contacts that help my career". The P motivation, "relieves guilt over being more fortunate than others" ranked lowest in importance as a motivation for volunteering.

The relatively low ranking of $\mathrm{C}$-related motivational factors is surprising in light of Simonson and Pals' (1990) study, which found "knowledge for job" as the third most important reason for volunteering as a $\mathrm{M}$ aster $\mathrm{G}$ ardener after "knowledge for self" and "self-improvement". Also, Jenner (1981) found that women view their volunteer role either as consciously chosen primary work, a supplement to primary work, or a vehicle for entry or return to employment. Ellis (1993) supports the idea that volunteering can foster career development and enhance the job search process. Indeed, in the current survey, females were more likely than males $(P=0.016)$ to indicate that the $M$ aster Gardener program allows them to explore different career options.

$D$ ifferences in responses by gender surfaced in several areas other than $\mathrm{C}$-related motivators. Females were more likely than males to indicate these as important reasons for volunteering: "I feel compassion toward people in need" ( $P$ $<0.01$ ), "I can learn how to deal with a variety of people as a M aster $G$ ardener volunteer" ( $P=0.01)$, "I am concerned about those less fortunate than myself" $(P=0.02)$, "Volunteering as a $M$ aster $G$ ardener is a way to make new friends" $(P=0.04)$, and "Through the $M$ aster $G$ ardener program I can explore my own strengths" $(P=0.05)$.

As might be expected, age also plays a role in the importance of $\mathrm{C}$ as a motivational factor in volunteering as a $\mathrm{M}$ aster $\mathrm{G}$ ardener. Career-related motives are negatively correlated with age. As age of respondentsincreased, importance of career motivational factors decreased (T able 5 ).

Current involvement level in the $M$ issouri $M$ aster $G$ ardener program differentially affected responses to many motivational factors. Those who volunteered more time during the past year were morelikely $(p<0.05)$ to highly rate the following reasons for volunteering:

\section{$\mathrm{H}$ elps me forget about feeling bad}

D o something for a horticultural cause important to me $M$ akes me feel needed

$\mathrm{H}$ elps me feel better about myself

Genuinely concerned about home gardeners

$C$ an explore my own strengths

Gain new perspective on things

Those close to me value community service

$M$ akes me feel important

People I know share an interest in community service

Way to make new friends

Feel it is important to help others

Volunteering is important to people I know best.

\section{Conclusions}

$\mathrm{M}$ isso uri $\mathrm{M}$ aster $\mathrm{G}$ ardener volunteers are motivated to contribute time to university extension horticultural education programs for a variety of reasons. Reasons related to increasing personal horticultural knowledge and opportunity to help others rank highest as reasons for volunteering. R easons related to career development, social aspects and protecting the ego tend to be ranked as a low priority. $\mathrm{H}$ owever, for certain volunteers, each of the 30 reasons examined may rank extremely high or extremely low in importance since the range of responses to each question on the seven-point Likert scale was from 1 through 7 , with the exception of the $\mathrm{U}$-related questions, "L earn more about horticulture and homegardening" and "L earn horticulture through hands-on experience", for which the range of responses was 2 through 7 (data not presented).

D emographic information is a poor predictor of motivation for volunteering. In most cases, no correlations or statistical differences were found among respondents belonging to different demographic categories. Exceptions included gender and age. Younger $\mathrm{M}$ aster $\mathrm{G}$ ardener volunteers and women are more likely to be motivated by $\mathrm{C}$ - 
related reasons. In addition, women are more likely to volunteer because they feel compassion toward people in need; they want to learn how to deal with a variety of people; they are concerned about those less fortunate than themselves; they see the $M$ aster $G$ ardener program as a way to make new friends; and they view the $M$ aster $G$ ardener program as a means of exploring their own strengths. All these reasons help explain why $M$ aster $G$ ardener programs typically have more female than male volunteers.

$U$ se of the VFI as part of the M aster Gardener application process could help determine the intent of a candidate to volunteer in the program. For example, volunteerswhose primary motivation is career related are likely to leave the program upon receiving training that prepares them for a career change or advancement. VFI results could also aid in volunteer placement, matching reasons for volunteering with likely outcomes of experiences. Since the knowledge function is so important to nearly all $M$ aster Gardener volunteers, it is vital to provide continued learning opportunities for them, in the form of advanced training sessions, periodic updates, newsletters, and on-the-job learning experiences.

Active $M$ aster $G$ ardener volunteers are more likely to ascribe greater importance to motivational factorsasreasons for volunteering than volunteers less involved. Further study is needed to determine whether the attribution of greater importance to specific reasons for volunteering could be used as a predictor of future involvement in the program, or whether the attribution is a result of having received personal benefits from volunteering. A separate article on benefits received from the $M$ aster $G$ ardener program (Schrock et al., 2000) addresses this research topic.

\section{Literature cited}

Carlton, K.D. 1981. Perceptions of M aster Gardeners regarding the training they received and the effectiveness of the $M$ aster $\mathrm{G}$ ardener program. M S thesis. U niv. Fla., G ainesville

Clary, E.G., M. Snyder, R.D. Ridge, J. Copeland, A.A. Stukas, J. $H$ augen, and $P$. M iene. 1998. U nderstanding and assessing the motivation of volunteers: A functional approach. J. Personality Social Psychol. 74(6):1516-1530.

Cronbach, L.J. 1951. Coefficient alpha and the internal structure of tests. Psychometrika 16(3):297-334.
Ellis, J.R. 1993. Volunteerism as an enhancement to career development. J. Employment Counseling 30:127-132.

Ferris, J.M. 1984. Coprovision: Citizen time and money donations in public service provision. Public Admin. Rev. 44:324-333.

Finch, C.R. 1997. Profile of an active M aster Gardener chapter. H ortTechnology 7(4):371-376.

Gordon, C.W. and N. Babchuk. 1959. A typology of voluntary associations. Amer. Sociological Rev. 24:22-29.

Guest, M . 1997. M aster G ardeners. N ational Gardening. (N ov.D ec.) 50-53.

$\mathrm{H}$ enderson, K.A. 1981. Motivations and perceptions of volunteerism as a leisure activity. J. Leisure Res. 13(3):208-218.

Henderson, K.A. 1984. Volunteerism as leisure. J. Voluntary Action Res. 13:55-63.

Jenner, J.R. 1981. Volunteerism as an aspect of women's work lives. J. Vocational Behavior 19:302-314.

M atell, M.S. and J. Jacoby. 1972. Is there an optimal number of alternatives for Likert-scale items. J. A ppl. Psychol. 56:506-509.

Piliavin, J.A. and H. Charng. 1990. Altruism: A review of recent theory and research. Annu. Rev. Sociol. 16:27-65.

Schrock, D.S., M. Meyer, P. Ascher, and M. Snyder. 1999. M issouri M aster Gardener demographics. J. Ext. 10 M ar. 2000. $<$ http:/ / joe.org/ joe/ 1999october/ rb4.html>.

Schrock, D.S., M. Meyer, P. Ascher, and M. Snyder. 2000. Benefits and values of the $M$ aster $G$ ardener program. J. Ext. 10 M ar. 2000. <http:/ / joe.org/ joe/ 2000february/ rb2.html>.

Simonson, D.L. and D.A. Pals. 1990. M aster Gardeners: Views from the cabbage patch. J. Ext. 28(3):35-36.

Stebbins, R. A. 1996. Volunteering: A serious leisure perspective. N onprofit Voluntary Sector Q uart. 25(2):211-224.

Sundeen, R.A. 1992. Differences in personal goals and attitudes among volunteers. Nonprofit and Voluntary Sector Q uart. 21(3):271-291.

Sundeen, R.A. 1988. Explaining participation in coproduction: A study of volunteers. Social Sci. Q uart. 69:547-568.

Thompson, A.M . III and B.A. Bono. 1993. Work without wages: The motivation for volunteer firefighters. Amer. J. Econ. Sociol. 52(3):323-343. 